\title{
Families in Spirit: Alliance of Prisoners' Families': Brief to the Standing Committee on Justice and Legal Affairs and Arlene Leigh Squiers
}

[Editor's Note: This brief was originally written in 1995 by seven women members of The Alliance of Prisoners' Families. In my comespondence with Amy Friedman Fraser, I inquired as to whether or not the original seven names should be attributed authorship. Her response to this question perfectly illustrates the dire situation of federal prisoners' families in Canada.

As far as the names listed, let's use just two, Amy Friedman Fraser \& Arlene Leigh Squires. The reason for this will also be clear as you read on. I haven't been in touch with the other women listed, and I don't know precisely how to contact them at this point. I know they won't be offended to be left off the list, and I fear adding their names at this juncture since I don't know what their situations are like at the moment. Again, this "fear" should be clear as you read on.

Sometime in 1994, Amy and Arlene met through a mutual friend. They were wary of each other. While prisoners' family members share many experiences, each one of us is an individual; despite efforts to stereotype both prisoners and their families, we are as different and as disparate from each other as are all individuals. Sadly, because we are often punished for our "associations," we most often feel a need to isolate ourselves in an effort to ensure our safety and our loved ones' safety. Fear of association with others in similar situations naturally leads to further isolation, alienation, sadness, hurt.

Still, one day in a tiny restaurant in Kingston, Ontario, Amy and Arlene sat down over coffee. Seven hours later, the seeds of the Alliance of Prisoners' Families and the brief to the SCJLA were born. Over the years -- through the anguish of involuntary transfers, gruelling parole board hearings, mounting phone and travel bills, and through sometimes aching loneliness and the exhaustion born of prison -- Amy and Arlene developed a deep respect for each other, and a friendship. Together they created The Alliance. The brief stands as the group's mission statement. Others joined, but many hesitate to put their names and/or faces to a document which might engender dire repercussions for themselves and/or for their loved ones in prison. Many, however, belong in spirit, and we believe that it is just that spirit -- a deep commitment to justice, integrity, honesty, and the strength of love and commitment in healing .. that will, ultimately, serve to keep at bay a 
desire for pure punishment and that will give a different, more accurate face to prisoners' families who embrace the notion of true justice.

Without the knowledge, commitment, energy, devotion, kindness, and supreme belief in justice offered us by both Claire Culhane and Graham Stewart, and by our husbands and other family members, we might have long ago given up in our struggles to endure the often debilitating concentration of misery and frustration that is prison. And so we thank Claire and Graham and our families, and we welcome others to join The Alliance of Prisoners' Families. (Contact through: The Alliance of Prisoners' Families, c/o Graham Stewart, The John Howard Society, 771 Montreal Street, Kingston, Ontario, K7K 3J4) [Correspondence to B. Gaucher: July 27, 1998]]

\section{INTRODUCTION}

$\mathrm{T}$ his brief is submitted with several purposes in mind. First, we want to bring to your attention the experience of families of prisoners in our attempts to maintain our ties and relationships with family who are incarcerated in our prisons. Second, we want to ask you to consider the reasons that the proper treatment of families and the support for our constructive relationships with our prisoners are of critical importance in the development of a correctional system that wishes to see its prisoners succeed after release. Third, we want to persuade you that the possibility exists that the practices of the Correctional Service of Canada (CSC) are often, indeed almost consistently, in contradiction to the spirit of its own mission statement, values and directives. Finally, we would like to ask you to consider implementing some modest proposals which would address the concerns we have brought forward.

We must open with a caveat. The Brief you are about to read may seem, to some of you, a bending of the truth, an exaggeration, perhaps even a lie. We can only say that we present the truth as closely as we are able to express it in words. We wish to speak to you about the very real operation of the CSC from our perspective. Ours are voices you seldom hear. We are prisoners' family members. While we cannot begin to speak for every prisoners' family member, we know that those most closely associated with prisoners must be heard, that our voices are a critical, if often ignored, component of any criminal justice system which hopes to succeed in any measure.

Our mission is, and has always been to encourage, promote, and foster successful rehabilitation and successful reintegration, to encourage, 
promote and foster justice and nonviolence. Few stand to lose more than we if our loved ones do leave prison only to reoffend. We are not only human beings who have, like Victims' Rights members, suffered severe loss (in some cases inside the prisons, in some cases outside as well), but we are human beings who, if the current system as it is practised prevails, will suffer greater harm and more loss. We are also law-abiding citizens of this country who rail, if silently, against the immense sums of money wasted in our prisons today and against the nonsensical decisions sometimes made by the National Parole Board.

As prisoners' family members, we live half of our lives behind those bars, in those cages, subject to the same whims of authority as are prisoners. We are constantly and consistently under siege by the Correctional Service in its Drug Strategy which effectively strips away our civil rights by presuming our guilt, using family access for punitive purposes, and punishing without giving an opportunity to challenge the accuser or the evidence. What few have considered is this: in general we are, without question, the members of this society with the strongest determination and deepest reasons to seek and strive for successful rehabilitation and reintegration of prisoners. We are your hope in large measure, and yet, we are treated as the very opposite.

We seek your political will. Our nation does, indeed, have in place policies, procedures and legislation which should go a long way towards creating prisons which heal rather than destroy. We hope you will recognize, however, that for us, many of our present policies, procedures and legislation are, in fact, failing. Any and all rewriting of legislation will continue to fail unless or until political will backs those documents. We attribute the current failures of the system to a lack of understanding and knowledge on the part of not only our legislators but of the nation as a whole. It is our hope to enlighten and to encourage you, as members of a Committee who will indeed impact this nation's legislators, to address the problems as they currently exist.

We ask you to remember that the vast majority of those individuals who have been incarcerated in this nation's prisons have also successfully returned to society to live crime-free, productive lives. Indeed, almost thirteen percent ( 2.6 million) of the adult population in Canada has a criminal record. Less than two percent of this group is incarcerated. ${ }^{1}$ The Service seldom refers to these "success" stories; the media almost never does. More importantly, perhaps, many of the successes are due not to the practices engaged in our prisons but to the will of individual human 
beings, oftentimes with the support of families. We can, we believe, increase that success and thereby better all of our lives.

We ask you to acknowledge that our voices and our stories join those of the Victims' Rights group members whose aim is sometimes, we believe, to better our system of justice. Victims' Rights groups however, often call for longer, harsher sentencing in the belief that this will decrease crime in this nation and increase the slippery, ill-defined notion of "public safety." It is our belief and experience that longer, harsher sentencing in general will go a long way towards leading this nation on the path the U.S.A. has taken, with the same results: a prison population that is exploding while an exceptionally high crime rate by all international standards prevails.

We wish to speak not only of prisoners whose crimes are said to be non-violent but of those whose crimes were. While there appears to be at present some political will to seek alternative measures to incarceration for nonviolent offenders, there appears to be, on the other hand, an increasing will to toss away the key that locks the cages of all those individuals who have, or are said to have, committed violent acts in their lives.

\section{THE BRIEF}

Oscar Wilde, while in prison, wrote: "Prison life makes one see people and things as they really are. That is why it turns one to stone."

The violence expressed by so many members of the public in their support of the will to punish those convicted of violent offenses more harshly and for longer periods; and the violence expressed by those who applauded the Emergency Response Team's (ERT) violent, humiliating action at the Prison for Women (P4W) in April 1994, turned us to stone for many months, convincing us not to appeal to the Committee back in 1994 and 1995, and on into 1996 and 1997, despite our having composed this Brief for review. We have long been silent due to lessons learned: that "official stories" are the acceptable stories, the stories both the general public and our politicians wish to hear about how our prisons in fact function, and that the "horror" stories such as the P4W event, Robert Gentles' death, Guy Paul Morin's conviction, are exceptions rather than the rule. 
Many of us have been silent for fear that our attempts to speak and/or write the truth would, as they have in the past, result in further degradation and loss through threats to ourselves, our children and punishment for our loved ones who are in prison. Alone, and sometimes with each other, we weep and rage about the way in which the Canadian people seem to accept as justifiable any and all acts taken against Canadian prisoners and their families. You must try to understand that if lawfulness and justice had played a part in many of the actions taken against our families, perhaps some of the psychological and physical assaults, financial exploitation, lies, censoring, threats and intimidation (in CSC' s own terms these are "criminal acts") taken against us might have been easier to bear.

Some prison officials with whom we have talked have assured us that we will never garner public or political support for prisoners or for ourselves in our never-ceasing attempts to seek justice. Prison officials have taunted us with their stalwart assurance that our desires and efforts to be seen as we truly are - individuals committed to living and promoting and supporting just, humane, sane, productive, nonviolent, noncriminal lives - will fail because the public cannot and will not distinguish between one prisoner and another, that the public will despise us because we are related to, care for, love a prisoner. The violence expressed by those who applauded the ERT's actions and by those who continue to support both the ERT's actions and the subsequent coverup of those actions by higher officials, has led us to believe this may indeed be true. It has made us hesitant and deeply fearful of stepping forward to speak with you. We have attempted to address these issues with the Correctional Service itself, but in 1994 we were informed by Mr. John Rama, of the Commissioner's Office, that there is "no perceived need on the part of Senior Administrators to meet with families of prisoners." Since that time, individuals among us have attempted to discuss individual issues. Seldom are we successful in obtaining even an interview or return phone call. Many (if not most) of our letters are disregarded.

The crimes committed by those we know and love in prison are crimes with which they will live forever, forever feel pain. The prison sentence was supposed to be the punishment for that crime - the reason for our laws, judges, juries, crowns, defence lawyers, police. But in our experience, the sentence all too often becomes instead, a license granted to those officials who choose to live their lives exploiting their own power 
over not only prisoners but over their loved ones and over society as a whole, causing pain and destruction.

At present, family members have no formal grievance procedure (beyond federal court which in most instances is far too costly and sometimes, when pursued, results in severe repercussions). We have few sources for reliable and informed information, little access to government officials except as rerouted through CSC officials who have expressed their disinterest in speaking with us. Even the lines of communication between prisoners and their loved ones are, in effect, subject to being whimsically cut off at any time (suspicions, Emergency Involuntary Transfers, lockdowns, being a few of the purported "reasons"). Prisoners, it must be remembered, live in daily peril and have no union, minuscule income, few official allies. Prisoners live in cages, sometimes for up to 23 hours a day, and in many instances these cages are far from their loved ones.

In $1995 \mathrm{CSC}$ issued a booklet containing advice to prisoners' families, in particular to spouses and children of prisoners. The booklet is designed to address the need to recognize abuse and the necessity of stopping the abuse cycle, first by recognition and then by the reporting of abuse. The booklet is, of course, aimed at those spouses who have been in the past/continue to be/or feel that they are being abused by their incarcerated spouses.

We read the booklet and realized that we have indeed been abused, have indeed suffered what CSC describes as "criminal abuse." But we have suffered this abuse by actions taken not by our loved ones but by the Correctional Service itself. This abuse has included but is not limited to:

- threat and intimidation of our loved ones and ourselves

- financial exploitation

- physical abuse (due to the method and manner by which CSC determines to engage in and engages in searches of visitors)

- $\quad$ attempts to halt our marriages

- our visits cut off with no legal cause

- illegal Emergency Involuntary Transfers (and subsequent false security ratings)

- $\quad$ sudden separation from the family and community support

- $\quad$ attempts to destroy our careers

- verbal abuse towards our children and interference in our children's ability to visit 
- $\quad$ attempt to halt legal work and to destroy legal businesses

- theft of work

- $\quad$ theft of money and other personal belongings

- tire slashings

- improper strip searches

- breach of Commissioner's Directives

- lies and distortions of paperwork (in particular by the IPSO, CSC's own secret police)

- administrative coverup of malice, abuse, negligence and incompetence

We recognize that it is your role to maintain a "neutral" stance in addressing issues that are brought to your attention, but we ask that you acknowledge that in order to be truly neutral, any halting of your ability to hear our stories will skew your perceptions and will help you to create a system that perpetuates the abuse cycle as it currently exists.

Our Justice Minister, our Solicitor General, our Prime Minister, our Commissioner speak of reason, public safety and justice. In our cases, in every instance of abuse levelled towards our husbands, ourselves, our children, the "excuse" offered us has been this. At some point our loved ones committed crimes for which they were sentenced to serve time in prison. We are told again and again, "the Service does not act without reason." If you accept these assertions, you will be unable to serve as "neutral" observers. If any and all reasons provided by the Correctional Service are adequate, any and all injustices will forever be hidden.

Some of us have responded to abuse by writing to administrators at the individual prisons, to Regional Headquarters officials, to the Correctional Service Commissioner, to the Correctional Investigator, to Citizens Advisory Committee members, to individual MPs. In most instances, our letters are ultimately responded to by an individual who, on occasion, apologizes for those infractions which are vividly evident and always reiterates the Correctional Service's Mission. These responses sit, largely unnoticed, in our own files. In some cases, the official response has gone beyond these letters. Some of us have read our own Correctional Service files - files compiled about those who are not prisoners. Large numbers of pages are blacked out in these files - information compiled about us but which we are forbidden knowledge.

It should by now be obvious, owing to the $\mathrm{P} 4 \mathrm{~W}$ incident at least, that administrators will make every effort to justify the actions taken by their 
employees and colleagues. Self-justification often stems from highly suspect information and continues to result in death, despair, poverty, murder, suicide, drug and alcohol abuse, anger, and frustration inside and outside our prisons. Please note that the suicide rate inside our prisons is over seven times that found outside of prison. It is 3.5 times the rate for young males aged 15-24 in the general Canadian population. The homicide rate inside prisons is fifteen times that within the Canadian population and eight times that of 18-39 year old males in the community. It is this kind of violence which our prisons foster. And it is this kind of violence which does, and will continue to impact upon society as a whole.

We have come forward because we realize that our silence will ensure the continuation of the current abuse cycle. Remaining silent despite all we know--that abuse is everyday fare for most prisoners and their families - flies in the face of our efforts at ensuring justice for all exists in this nation.

\section{SOME MOdest Proposals}

Although our concerns are substantial, our proposals are modest. We recognize that substantial change is unlikely on the basis of this submission. We do not think that you will be entirely persuaded by our claims that serious problems are at the root of the operation of our prisons. We hope, however that our testimony might raise in you mind the possibility that these problems do exist. That alone should be troubling. We have, therefore, tried to identify a few proposals that should not be controversial but which have the potential to address this possibility, make important changes that will help us succeed in our lives and thereby create a greater likelihood of our nation as a whole becoming safe, sane, more democratic.

\section{The Correctional Investigator's (CI) Office}

Under current legislation, the Cl's function is as follows:

It is the function of the Correctional Investigator to conduct investigations into the problems of offenders related to decisions, recommendations, acts or omissions of the Commissioner or any person under the control and management of, performing services for or on behalf of the Commissioner that affect offenders either individually or as a group. [emphasis added] ${ }^{2}$ 
Unfortunately, the CI's Office is understaffed and underfunded and unable, therefore, to attend to the vast numbers of decisions, recommendations, acts, and omissions on the part of the Commissioner and those under his control and management. Representatives of the Investigator's Office are located far from the prisons themselves and are only able to get to each prison infrequently (approximately every four months). Access to the Investigator, and the ability of the Investigator to obtain vital information, is thereby inhibited. The CI's Office is mandated to address family concerns as well, though few families are aware of this mandate, and CI officials seldom have contact with family members.

\section{We propose:}

a. that you seek a hearing with the Correctional Investigator to better understand the nature of the issues requiring that office's attention; and,

b. that the Cl's office recognize that decisions, recommendations, acts and omissions on the part of CSC staff and administrators towards family members do indeed impact offenders and are, thereby, within that office's mandate to investigate and address.

\section{Family input into Correctional Service Policy Making}

Any policy decisions made and actions taken which directly impact upon us, will be ineffective and will inevitably fail, if we are not involved. Please remember, it is against us that these sanctions are imposed. Effective democratic systems require the participation of representatives of those parties directly involved.

\section{We propose:}

a. that before policies such as the most recent Drug Strategy (and CSC's "Best Practices") are adopted, representative family members of prisoners (from at least each Region) be consulted.

\section{Establishing Positive Accountability}

It is currently presumed that prisoners alone must be accountable and must somehow prove their innocence when accused of any and all wrongdoings (beyond the crime for which he or she is sentenced). This presumption of guilt of prisoners (and their visitors) is in direct contradiction to all principles of democracy. 
Public perception of prisoners and their families, fostered by media stories provided by Administrators at CSC continues to promote the notion that all prisoners are guilty of all acts for which they are accused, even beyond those acts for which they have been sentenced to serve time. This image persists despite overwhelming evidence to the contrary (particularly regarding the post release success of Lifers ${ }^{3}$ ). All prisoners, nonetheless, are perceived and represented as forever dangerous to society at large.

It is our view that CSC is held to account for negative events such as escapes and decisions to release prisoners who subsequently reoffend but is seldom asked to demonstrate its effectiveness at rehabilitation. It is because of this one-sided accountability that families can be viewed as a nuisance to CSC, when in fact, they should be seen as a major asset to its mission.

\section{We propose:}

a. that the Correctional Service prepare an annual report to be submitted to Parliament and reviewed by the Correctional Investigator which details: how the Service has met its rehabilitative goals; contributed to successful earliest possible reintegration of prisoners into the community; has addressed citizen and prisoner complaints about unfair practices and previous recommendations made by the Correctional Investigator. These reports should be made available to the public.

\section{Input to the Committee from Prisoners and Family Members}

Family members and those men and women sentenced to serve long sentences can tell Committee Members precisely how their efforts at rehabilitation have succeeded and/or failed and the part that CSC practices have played in this success or failure. We are confident that most Lifers' Groups, for instance, would welcome Committee Members.

\section{We propose:}

a. that members of the Justice and Legal Affairs Committee visit prisons and speak with those unable to appear before the Committee so that legislation recommended address the realities of prison life and prisoners themselves. 


\section{ENDNOTES}

1. Basic Facts About Corrections in Canada, 1993 Edition, Canada: Solicitor General, 1994:2

2. Correctional Investigator, Mandate, Canada: Solicitor General

3. Of 75 murderers released in $1986,14.6 \%$ re-offended - none for murder - over the subsequent five year period. Source: Weeks, J. R. "Long -Term Offenders: Who Are They and Where Are They," Forum on Corrections Research, Vol. 4, No. 2, Correctional Service of Canada, June 1992.

\section{CirCle OF HoPe WOMEN's GROUP}

CIRCLE OF HOPE IS A PROGRAM OF JUSTUS, A SPIRITUALLY BASED NONPROFIT CHARITABLE ORGANIZATION IN TORONTO. JUSTUS WORKS TO ELIMINATE FEAR AND PREJUDICE BY CREATING RELATIONSHIPS AMONG INMATES, EX-INMATES, THEIR FAMILIES AND THE LARGER COMMUNITY. THE COORDINATOR, MARIA KaRAJOVANOVA CAN BE REACHED AT:

$\begin{array}{lrr}\text { EMMANUEL-HOWARD PARK } & \text { PHONe: } & (4 \mid 6) 534-9133 \\ \text { UNITED CHURCH } & \text { FAX: } & (4 \mid 6) 534-3355\end{array}$

214 WRIGHT AVENUE

TORONTO, ON MGR IL3

Circle OF HOPE IS A GROUP FOR WOMEN WHO ARE CURRENTLY SUPPORTING (OR HAVE IN THE PAST) A LOVED ONE IN PRISON. WE OFFER THE OPPORTUNITY TO SHARE OUR EXPERIENCES, PRACTICAL ADVICE, INFORMATION AND RESOURCES. WE ENCOURAGE A SPIRIT OF SELF-CARE AND SELF-EMPOWERMENT IN A SAFE AND FRIENDLY ATMOSPHERE. BE PART OF A SUPPORT NETWORK OF WOMEN YOU CAN RELATE TO AND TRUST.

AS WOMEN SUPPORTING A LOVED ONE IN PRISON, WE ARE IN A VERY UNIQUE SITUATION. THE DAILY PRESSURES AND STRESSES PLACED ON US ARE MANY. WE TEND TO TAKE ON A NURTURING ROLE EVEN MORE SO THAN USUAL AND OFTEN FIND IT DIFFICULT TO REMEMBER THAT WE NEED TO TAKE CARE OF OURSELVES. WE ARE FREQUENTLY ISOLATED FROM OUR FRIENDS, FAMILIES, CO-WORKERS AND SOCIETY AS WELL AS THOSE BEHIND BARS: OUR SITUATION MAKES IT DIFFICULT TO RELATE TO OTHERS WHO DON'T SHARE OUR EXPERIENCES AND THE CIRCUMSTANCES DO NOT 
ALLOW FOR NATURALLY CREATED BONDS AMONG US IN WHICH WE CAN SUPPORT AND BE SUPPORTED BY ONE ANOTHER.

THE WOMEN'S GROUP PROVIDES A FORUM WHERE WOMEN WHO SHARE THE EXPERIENCES OF SUPPORTING A PRISONER CAN MEET TO EXPRESS CONCERNS AND NEEDS AND POOL RESOURCES AND INFORMATION SURROUNDING THIS CIRCUMSTANCE. SHARING THE COMMONALITY OF THEIR EXPERIENCE, WOMEN ARE ABLE TO OFFER COMPASSIONATE INSIGHT AND PRACTICAL ASSISTANCE TO OTHERS WHO HAVE HAD OR NOW HAVE LOVED ONES WHO ARE INCARCERATED. OUR GROUP OFFERS AN OPPORTUNITY FOR FURTHER VOLUNTEER INVOLVEMENT FOR THOSE WHO WISH TO STUDY OR WORK ON ASPECTS OF ADVOCACY AND PUBLIC EDUCATION WITH RESPECT TO THE CANADIAN PENAL SYSTEM. 